\title{
The Degree that Nature of Scientific Knowledge Aspects are Included in the Science Classes of Greek High Schools
}

\author{
Anna Koumara ${ }^{1, *} \&$ Katerina Plakitsi ${ }^{1}$ \\ ${ }^{1}$ Department of Early Childhood Education, School of Education, University of Ioannina, Greece \\ *Correspondence: Department of Early Childhood Education, University of Ioannina, Greece. Tel: \\ 30-693-800-36625. E-mail: anniekmr@gmail.com
}

Received: June 15, 2020

doi:10.5430/wje.v10n5p1

\author{
Accepted: September 8, $2020 \quad$ Online Published: October 10, 2020 \\ URL: https://doi.org/10.5430/wje.v10n5p1
}

\begin{abstract}
The present study examines the integration level of the Nature of Scientific Knowledge in secondary school science classes in Greece. The research was designed and organized on the basis of the Cultural-Historical Activity Theory. The activity system of the researchers, who use the proper tools each time, are in network relations with the activity system of Science Education. Major components of the educational system are studied (the curriculum, textbooks, teachers' know-how and teaching methods, school inspectors' viewpoints, students' knowledge) in relation to the nature of scientific knowledge, to ensure valid results. The curriculum and textbook content is decoded, the knowledge of teachers and students is assessed with the use of an internationally validated questionnaire, and interview protocols are analyzed. Research results reveal that the nature of scientific knowledge is included in a small degree in the curriculum and textbooks, teachers refer intuitively to some of these aspects, without assessing the knowledge of students, and, finally, the majority of high-school graduate students have naïve views regarding the nature of scientific knowledge.
\end{abstract}

Keywords: nature of science, secondary education, Greece

\section{Introduction}

\subsection{The Problem}

This study presents the results of the research that took place in Greece aiming to examine the integration level of the Nature of Scientific Knowledge (NOSK) in science classes in the secondary education system (grades 7-12, students aged 12-18). It is part of a wider project which started with the Need Analysis, as presented here, and was later followed by the design and implementation of a professional development (PD) program for science teachers, regarding NOSK teaching (see paragraph 4).

An initial research (Koumara \& Plakitsi, 2017) revealed that NOSK teaching in Greece is problematic. The present study aims to expand the research in the entire secondary education system (the former study focused on Lower Secondary School, grades 7-9), using more tools, statistical analysis and interviews conducted both with teachers and students. Another goal is to study the cultural characteristics of teachers, their historicity and the activity system of science classes, and analyze them based on the Cultural-Historical Activity Theory (CHAT) in order to facilitate the design of a PD-program for science teachers in the future (Roth \& Lee, 2007). CHAT serves to the multi-faceted depiction of the problem.

The views of students and pre-service and in-service teachers regarding NOSK (e.g. Akerson \& Abd-El-Khalick, 2005; Lederman, Abd-El-Khalick, Bell \& Schwartz, 2002; Schwartz \& Lederman, 2008; Stefanidou \& Skoroulis, 2018) have been recorded and researched since the early days of this field (Lederman, 1992) and their analysis continues until today (e.g. El-Takach and Yakoubian, 2020). There are many assessment tools specifically designed to achieve valid results (Abd-El-Khalick, 2014). The initial studies were conducted in North America but have now expanded to the rest of the world, e.g. BouJaoude and Santourian (2012) in Lebanon, Dogan and Abd-El-Khalick (2008) in Turkey, Leden, Hansson, Redfors and Ideland (2015) in Sweden, Thye and Kwen (2004) in Singapore. Especially in Turkey, this study is part of a wider government-funded project, named BIDOMEG, the initials of 
which stand in Turkish for "Continuing Professional Development to Support the Teaching about Nature". The researchers designed, among others, an assessment questionnaire and activity books (Yalaki, Dogan, Irez, Dogan, Cakmakci, \& Kara, 2019). Regarding NOSK in school textbooks, Abd-El-Khalick, Waters and Le (2008) turned their work in this field in a book, edited by Abd-El-Khalick and McDonald (2017). There is a chapter in this book with Kampourakis' study (2017) on Greek biology textbooks. Finally, there are studies on curricula, like Naser's (2018) for Palestine or the review of the United Kingdom curriculum (Jenkins, 2013).

The present study differs from the ones mentioned above because it concerns Greece and contains the study of all the components of its educational system: the curriculum, textbooks, student and teacher views on NOSK aspects (see 2. Method), in order to a) draw broader conclusions about NOSK teaching in this country and b) create a PD-program for science teachers, taking into consideration the cultural characteristics of teachers and the curriculum and textbook requirements.

\subsection{The Nature of Scientific Knowledge and Why its Teaching is Important in Compulsory Education}

For the past 100 years, the definition of Nature of Science (NOS) and its aspects has been a matter of constant debate between philosophers/historians/sociologists of science and educators. Until today, there is no consensus on its definition and its aspects (Lederman, Antink \& Bartos, 2014; Piliouras \& Plakitsi, 2015; Lederman, 2019; McComas, 2017; Clough, 2007; Allchin, 2011; Matthews, 2012; Erduran \& Dagher, 2014; Van Dijk, 2011). However, all of them acknowledge the importance of NOS aspects in Science teaching. They argue that NOS a) provides a better understanding of the limitations of science, $b$ ) increases interest in classroom, c) achieves better understanding of scientific knowledge, and d) achieves scientific literacy (Matthews, 1997; Lederman, 2019). Especially, scientific literacy is widely recognized and incorporated in the global science curricula (Allchin, Andersen \& Nielsen, 2014, Lederman et al, 2014). They also agree that teaching needs to be carried out in an explicit and reflective manner. In the present study, we prefer to use the term "Nature of Scientific Knowledge" (NOSK) to refer to the characteristics of scientific knowledge that are inherently derived from the manner in which it is produced (Scientific Inquiry). In this context, we accept the framework proposed by Lederman (Lederman et al, 2014, Lederman 2019). The main reasons for this decision is a) the great volume of implementation studies in various countries and populations (students, pre-service teachers, in-service teachers) and the extensive availability of highly validated and reliable assessment tools (VNOS questionnaires). This allows us to compare our results with other studies and facilitates b) the design and implementation of a PD-program for science teachers with NOSK aspects for the continuation of the project. The Lederman group was chosen because their thirty-year research experience makes them probably the most cited and influential researchers in this field (Matthews, 2012). According to our estimations, their suggestions are the easiest to adopt in Greece, in comparison to other frameworks.

The NOSK aspects are (Lederman et al 2014):

\section{(A1) Scientific knowledge is empirical}

Scientific knowledge is based on /derives from empirical data.

\section{(A2) Observations and inferences are different}

"Observations" are descriptions of natural phenomena that are directly accessible to the senses, or expansion of them. They are subject to limitations of existing equipment and the dominant theory, but observers usually reach consensus on what they see, hear, feel, etc. "Inferences" are the explanation of observations and the same observations could lead to different inferences, according to the background of researchers.

\section{(A3) Scientific knowledge is creative}

Scientific research - contrary to common belief - is not a rational and orderly process. Creativity and imagination is required in every part of the research: in design, data collection and creation of interpretations; it is similar to the creative process of an artistic work.

\section{(A4) Even though objectivity is the goal, subjectivity within scientists is unavoidable}

All scientists are susceptible at every stage - interpretation of results, observations and research design - to their own personal beliefs, prior knowledge, training, expectations, etc. Therefore, even though objectivity has always been the goal in Science (through the use of standard scales and precision in measurement), subjectivity is unavoidable. Also, Science is a social activity. Scientists are interacting with each other through scientific publications; their reviews and the continuous testing are meant to enhance the objectivity of their methods.

(A5) Scientific knowledge is durable, but subject to change in the light of new evidence 
Scientific knowledge is reliable and durable, albeit relative and uncertain. It is subject to change every time new evidence comes to light due to the evolution of technology or new interpretations of older evidence.

\section{(A6) Socio-cultural embeddedness of Science}

Science is a human endeavor that affects and is affected by all societal, cultural, philosophical, religious, political and economic factors.

\section{(A7) Scientific Laws and Theories are different types of knowledge}

Laws are generalized descriptions of relationships among observable phenomena and are based on many observations. They describe what happens in the (usually idealized) natural world, but never explain why. Those inferred explanations are provided by Theories.

\subsection{CHAT Framework}

Cultural-Historical Activity Theory (CHAT) is a "cross-disciplinary framework to study how humans purposefully transform natural and social reality, including themselves, as an ongoing culturally and historically situated process (Roth et al, 2012). Vygotsky introduced CHAT and Leontiev (1978) expanded on it, with his perception on a collective system of human activity. Engeström (1987) presented Leontiev's views using the triangle for human activity systems (see Figure 1).

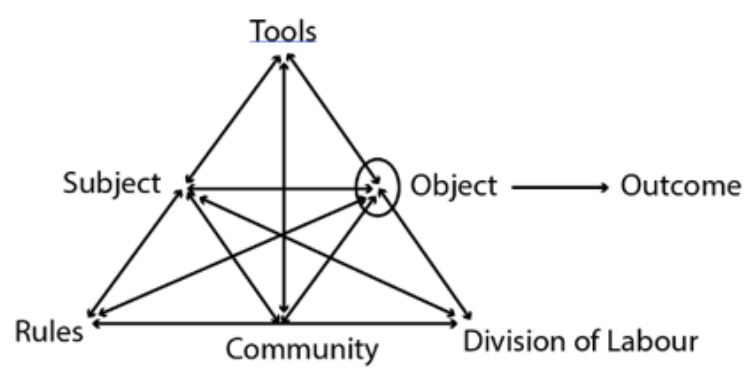

Figure 1. The Structure of a Human Activity System

The relations between the Subject (usually people, lately they are also corporations, moving towards a desired goal) and the Object (the activity goals) are mediated through tools, the community, the rules and division of labor. Tools/artefacts are culturally-produced means that subjects use to perform the activity. They may be material, like a magnet, a telescope, or mental, like language. Community refers to all the participants who share the same object that shapes and directs individual actions to the collective activity. Division of labor refers to the way subjects, as members of the community, divide their responsibilities during an activity. The triangle of the activity system refers both to the horizontal actions and interrelations between the members of the community and the vertical distribution of power, resources and relative societal/professional status. The nodes of an activity system are not static and isolated to each other, but they are dynamically connected; the system is regarded as a unity (Hasan \& Kazlauskas, 2014; Kolokouri \& Plakitsi, 2016; Barma, 2011; Plakitsi, 2013; Kornelaki \& Plakitsi, 2018; Igira \& Gregory, 2009).

In the present study, we use Engeström's model because it fits to the needs of our research, indicating the factors that need to be studied in order to answer our research question. The results of the educational activity system are more complex due to its interaction with other activity systems (Engeström, 2001, Engeström, 2009; Kornelaki \& Plakitsi, 2018; Plakitsi, 2013). The entire CHAT framework is presented in another paper (Koumara \& Plakitsi, 2019) and will be applied for the continuation of this project.

\section{Method}

Education, in general, and more specifically in Science, is a complex activity system with various parameters. Its complexity could be illustrated using CHAT (Kolokouri \& Plakitsi, 2016), as shown in Figure 2.

In order to evaluate the level of integration of NOSK aspects in the teaching of Greek secondary school science classes, all components of the educational system recorded in Figure 2 are studied, apart from the educational policy makers and textbook authors. The research focuses on science classes from $7^{\text {th }}$ Grade until $11^{\text {th }}$ Grade. $12^{\text {th }}$ Grade is not included in our research, because it is a preparatory year for university entrace exams and students specialize in particular subjects; as a result, not all students follow Science courses. For the purposes of this research, we examine 
what all students are taught in Secondary Education.

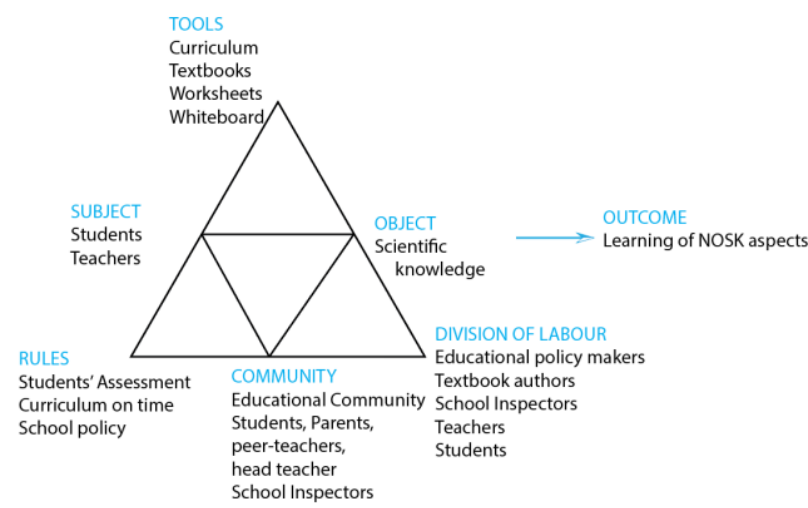

Figure 2. Activity System of Science Education in Secondary Schools in Greece

The researcher, the Subject in their own activity system (see Figure 3), in order to assess:

1. Whether the teaching of NOSK aspects was suggested in science curricula and included in textbooks (tools in Figure 2), studied 1) the science curricula, and 2a) all subject textbooks, and also studied and classified 2 b) the recommended textbook exercises.

2. Whether science teachers (subjects in Figure 2) were aware of NOSK aspects, 1) asked 50 science teachers from Thessaloniki, Greece to complete the VNOS-D+ questionnaire (Lederman et al. 2002) and 2) interviewed 10 of them.

3. Whether science teachers assessed (rules in Figure 2) NOSK aspects in the final exams, the researcher analyzed the final exam content.

4. Whether school inspectors (members of the community in Figure 2) knew if NOSK aspects were taught in science classes, they interviewed $7 \mathrm{School}$ Inspectors from all regions of Greece.

5. Whether high-school graduates ${ }^{1}$ (subjects in Figure 2) were taught and were aware of NOSK aspects, the researcher 1) asked 149 students to complete the VNOS-D+ questionnaire (Lederman et al. 2002) and 2) interviewed 30 of them. 


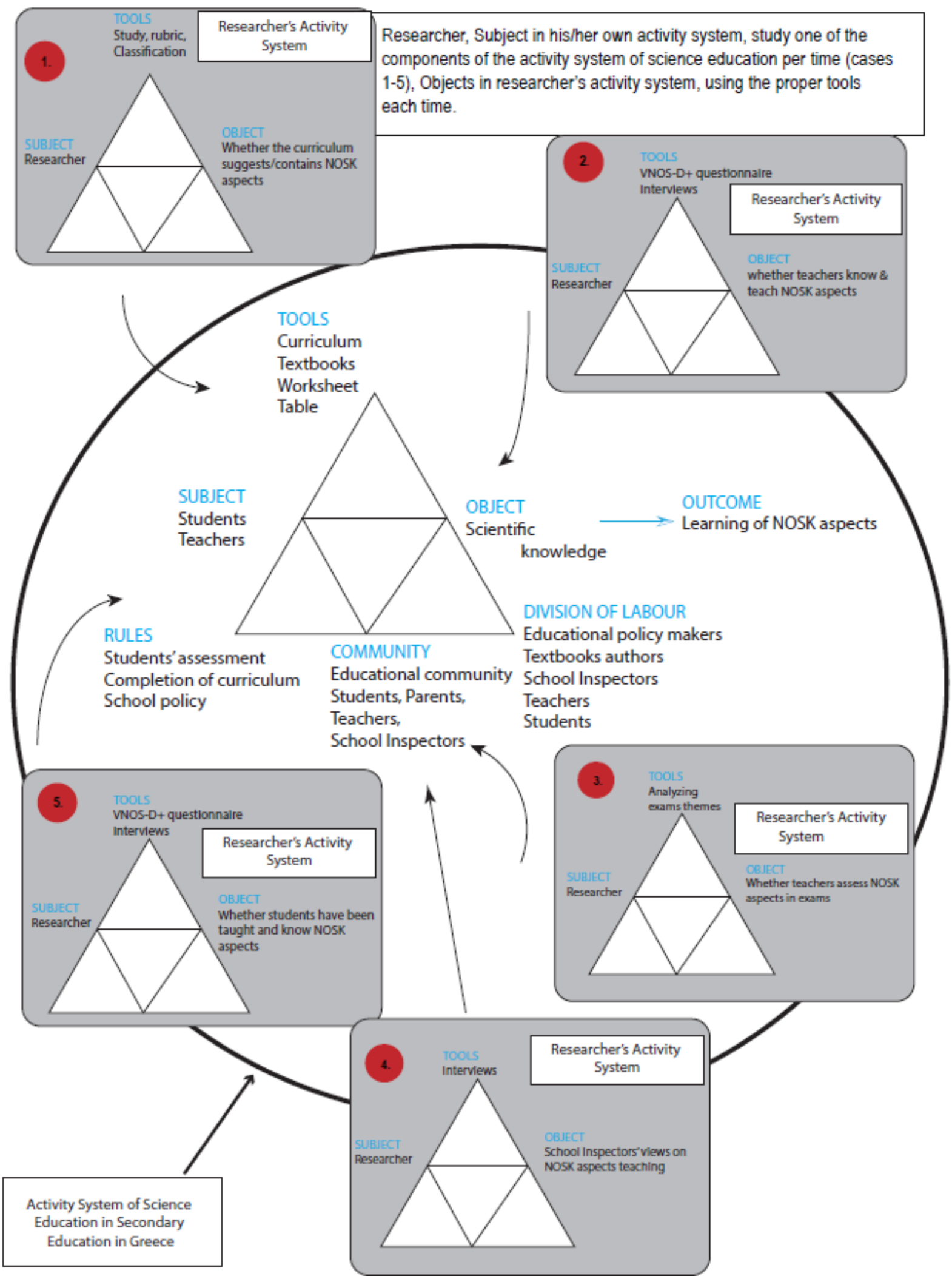

Figure 1. Research on the Activity System of Science Education in Secondary Education in Greece 


\section{Results}

\subsection{Curriculum}

Curricula for all Science subjects in Lower Secondary School, apart from $7^{\text {th }}$ Grade Physics, were published in 2003 and used in the school year 2007-08. Regarding $7^{\text {th }}$ Grade Physics, the curriculum was published in 2013 and used in the school year 2013-14, when the subject was introduced for the first time.

The general part of all curricula is oriented towards scientific literacy, but neither the NOSK term (or any similar one), nor any of its aspects are mentioned.

The special part of curricula includes primarily cognitive goals and secondarily goals for inquiry skills. NOSK is not mentioned explicitly. However, if teachers are aware of NOSK aspects and wish to integrate them in their lessons, the curriculum allows them to do so. It is noted that a new Physics curriculum (Plakitsi et al., 2011) included NOSK, but, even though it was successfully piloted in 100 schools, it was not generally applied and did not lead to the writing of new textbooks.

Regarding Higher Secondary Education, the textbook content was based on the Science Curricula published in 1999. In recent years, there have been many changes, mainly the removal of specific chapters and rearrangements in the curriculum, i.e. some chapters that were originally written for one grade are taught in another. In other words, new curricula have been published, as modified versions of the 1999 ones, and no new books have been written.

In Science Curricula of Higher Secondary Education, no NOSK aspects are included, nor the term itself. However, there are objectives upon inquiry and references to everyday life which allow science teachers to include NOSK aspects in their lessons, if they are aware of them and they wish to do so.

\subsection{Textbooks}

\subsubsection{Content of Textbooks}

It is internationally recorded that Curricula are regularly substituted by textbooks, which control what is taking place inside the classroom (Abd-El-Khalick et al, 2017). Teachers usually rely on textbooks for daily instructions and use of their recommended student exercises, either for use in the classroom (75-90\% of teachers) or for homework $(90 \%$ of teachers). This happens either due to lack of time, or due to lack of knowledge ${ }^{2}$, or because there is only one official textbook (DiGiuseppe, 2014; McDonald \& Abd-El-Khalick, 2017a).

Greece has only one official textbook for each subject, which is compulsory in all private and public schools in each grade. Teachers traditionally work with the textbook and not the curriculum. The content of textbooks and their proposed exercises play an important role in the teaching of science and consequently in learning, since they are extensively used in the daily teaching process determining to a great extent the final learning outcome (Anagnostopoulou, 2015, p.175).

In order to assess the reference of NOSK aspects in textbooks, a rubric, adjusted from Abd-El-Khalick et al (2017), is used. The scoring of each NOSK aspect is based on the criteria described in Table 1:

Table 1. Criteria for Textbooks Scoring

\begin{tabular}{clcl}
\hline Score & Representation of each NOSK aspect & Grade & Representation of each NOSK aspect \\
\hline 3 & Explicit, informed, consistent & -1 & Implicit, naive \\
2 & Explicit, partially informed & -2 & Explicit, naive \\
1 & Implicit, informed, consistent & -3 & Explicit, naïve, non-consistent \\
0 & Not addressed & & \\
\hline
\end{tabular}

An initial study on textbooks, prior to scoring with the use of the rubric, indicated that the reference of NOSK aspects is limited. Phrases like "nature of scientific knowledge" and "this is how scientists think/work", and other similar ones, were missing from textbooks. Direct references on NOSK aspects were few. Therefore, the explicit representation score would be near 0 for all textbooks. However, this will not allow us to identify the actual differences between textbooks, for example, the significant differences between $8^{\text {th }}$ Grade Chemistry and Biology.

We considered the possibility of reaching conclusions regarding the reference of some NOSK aspects examining the vocabulary used in textbooks, for instance, the use of verbs such as "observe", "conclude", etc. Consequently, we decided to be more lenient regarding the explicit/implicit representation of these aspects. Therefore: 
- The representation of a NOSK aspect was categorized as Explicit/Implicit; this was determined by the content of written information that teachers would receive and whether this allowed them to make reference to these aspects or not.

- The representation of a NOSK aspect was categorized as Informed/Partially Informed/Naïve based on its reference in school textbooks. If an aspect was addressed correctly it was categorized as "informed"; if it was addressed to the correct direction but its formulation was problematic, it was categorized as "partially informed"; and, if it was addressed incorrectly and was misleading, it was deemed as "naïve". The "correct" and "incorrect" directions are defined by the international literature on NOSK aspects.

- The content was assessed based on the consistency of the representation of each NOSK aspect in the entire textbook.

The rubric is limited since scoring does not include the position of each recorded aspect. For example, introductions and appendixes are not usually read by students, contrary to the main body of the text.

Results of the study are summarized in Table 2:

Table 2. Scoring the Science Textbooks Using the Rubric

\begin{tabular}{ccccccccccccc}
\hline Grade & \multicolumn{1}{c}{ Physics } & \multicolumn{3}{c}{ Chemistry } & \multicolumn{5}{c}{ Biology } \\
\hline NOSK aspect & $7^{\text {th }}$ & $8^{\text {th }}$ & $9^{\text {th }}$ & $10^{\text {th }}$ & $11^{\text {th }}$ & $8^{\text {th }}$ & $9^{\text {th }}$ & $10^{\text {th }}$ & $11^{\text {th }}$ & $7^{\text {th }}$ & $8^{\text {th }}-9^{\text {th }}$ & $10^{\text {th }}$ \\
A1 & 2 & 3 & 3 & 3 & 3 & 3 & 1 & 2 & 2 & 1 & 0 & 0 \\
A2 & 2 & 2 & 2 & 1 & 1 & 2 & 1 & 1 & 1 & 0 & 1 & 0 \\
A3 & 0 & 0 & 0 & 0 & 0 & 1 & 1 & 1 & 0 & 1 & 0 & 0 \\
A4 & 1 & 0 & 0 & 0 & 1 & 2 & 1 & 2 & 0 & 0 & 0 & 0 \\
A5 & 1 & -1 & -1 & 2 & 2 & 2 & 1 & 3 & 2 & 1 & 1 & 0 \\
A6 & 1 & 0 & 0 & 0 & 0 & 3 & 2 & 0 & 2 & 0 & 0 & 0 \\
A7 & 0 & -3 & -1 & 0 & 0 & 0 & 0 & -2 & 0 & 0 & 0 & 0 \\
Total & 7 & 1 & 3 & 6 & 7 & 13 & 7 & 7 & 7 & 3 & 2 & 0 \\
\hline
\end{tabular}

The conclusions from Table 2 are:

1) Apart from Biology textbooks, the rest of them provide the opportunity to teachers to refer to NOSK aspects, if they are aware of them and should they wish to do so.

2) The empirical aspect in Lower and Higher Secondary School textbooks, the difference between observations and inferences in the Lower Secondary School textbooks and the tentative aspect in Higher Secondary School textbooks have the highest scores. The lowest scores are on the creative thinking aspect both in Lower and Higher Secondary School, the social and cultural embeddedness for Higher Secondary School, while the difference between theories and laws receives negative scores.

3) Regarding Biology, our results are in agreement with Kampourakis (2017), who claims that both textbooks and the Curriculum provide opportunities - some very implicitly though - for integration in teaching to those who are aware of NOSK aspects. Kampourakis raises the question which will also preoccupy us later, whether teachers are actually aware of NOSK aspects.

However, despite their scores, the total absence of the term "nature of scientific knowledge" is highlighted in textbooks, whereas when NOSK aspects are mentioned, these appear exclusively in chapter introductions or appendixes, which are not usually assessed. As a result, it is highly likely that these parts are not being taught.

\subsubsection{Student Exercises in Textbooks}

Most of the suggested exercises for students in textbooks test cognitive knowledge and almost none of them is related to NOSK aspects. Specifically, only 15 out of $2261(0.7 \%)$ questions/exercises were related to aspect A2 (observations and inferences) but the difference between observations and inferences was not clear. Regarding the suggested projects, which could also be used for assessment, around half of them in each subject could be related to NOSK aspects. However, their formulation is very generic, and they could incorporate NOSK aspects only if the teacher wishes to provide that direction in their lessons. Another study concluded that the recommended exercises in Lower Secondary School textbooks test cognitive knowledge by $92.7 \%$ and only a $7.3 \%$ assesses the knowledge of science, part of which is related to NOSK (Anagnostopoulou, 2015, p.270). 


\subsection{Teachers}

\subsubsection{VNOS-D+ Questionnaire}

Apart from the Curricula and the textbook content, teachers can interpret instructions as they wish. Therefore, an interesting question is whether teachers are aware of NOSK aspects (Lederman \& Lederman, 2014). To study the above question, in April 2018, 50 science teachers were asked to complete the internationally validated VNOS-D+ questionnaire (Lederman et al, 2002).

VNOS-D+ questionnaire is an acronym for "Views of Nature of Science" and consists of 10 open-ended questions, which target directly or indirectly the knowledge of one or more NOSK aspects. "Directly" means that the answer on a question is linked to an aspect, whereas "indirectly" means that the answer on a question may or may not be linked to that aspect (Lederman et al, 2014). Question 4 has four sub-questions.

According to the guidelines provided by the creators of the questionnaire ${ }^{3}$, NOSK aspects are detected from the questions as presented in Table 3:

Table 3. Questions and Targeted NOSK Aspects

\begin{tabular}{ll}
\hline Targeted NOSK aspects & Questions \\
\hline Empirical & $4 \mathrm{~d}$ and 2 indirectly \\
Difference between observations and inferences & $4 \mathrm{a}, 4 \mathrm{~b}, 4 \mathrm{c}, 5,6$ and 3 indirectly \\
Based on creative thinking & 7 and 2 indirectly \\
Subjective/Objective & $4 \mathrm{c}, 7$ and $1,2,3$ indirectly \\
Tentative & $3,4 \mathrm{~b}, 5,9$ and 1 indirectly \\
Social and cultural embeddedness & 10 \\
Difference between theories and laws & 8 \\
\hline
\end{tabular}

The sample consists of 50 science teachers in public and private schools in the region of Thessaloniki, Greece, of whom 18 were men and 32 women; there were 32 physicists, 3 geologists, 6 biologists and 9 chemists. All but one had permanent placements, and were aged between 35 and 60, with an average around 50. Since their placement in Thessaloniki was permanent, they had either many years of teaching experience or high academic qualifications (Master's or PhD degrees). Science teachers would participate voluntarily in a PD-program on NOSK taking evening classes (see paragraph 4) and their answers were the pre-test. Teachers who traditionally attend those PD-programs are motivated to learn and improve their teaching, as they do not receive certificates of attendance [which would otherwise be useful for promotions or similar use].

Questionnaires were scored twice within four months by the first author, after being trained by the creators of the questionnaire. At the same time, she trained two other researchers enabling them also to score. The three researchers attributed the final scores in unison, reaching consensus of agreement at $91 \%$.

Each question was scored in 4 categories:

- N-Naïve: when the answer indicated that the teacher had a misrepresented view on the specific NOSK aspect

- M-Mixed: when the answer indicated that the teacher knew some elements on the specific NOSK aspect, but not sufficiently

- I-Informed: when the answer indicated that the teacher had an informed (correct) view about the specific NOSK aspect

- $\mathrm{I}^{+}$-Super Informed: when the given answer was well-documented, well-formulated and could be given as an excellent correct example for the specific NOSK aspect in question

- U-Unanswered: for questions that teachers did not answer

The difference between informed (I) and super-informed (I+) responses is defined by the vocabulary used (for example, the use of certain keywords), whether an example is mentioned or if there is a more analytical description in $\mathrm{I}+$ responses in comparison to I. Both categories include correct responses.

To score the responses, it was important to create the "profile" of each participant for every NOSK aspect. To enhance their "profile", the first author interviewed $20 \%$ of the participants, as instructed by the creators of the questionnaire. Interviews took place after the researcher scored the questionnaires for the first time. At each interview, the interviewee answered each question of the VNOS-D+ orally. If the researcher discovered a mismatch 
between what they meant and what they had written (or between what the researcher thought they meant) she changed her score and noted it down for the other researchers.

The overall results are presented in Figure 4 and Table 4:

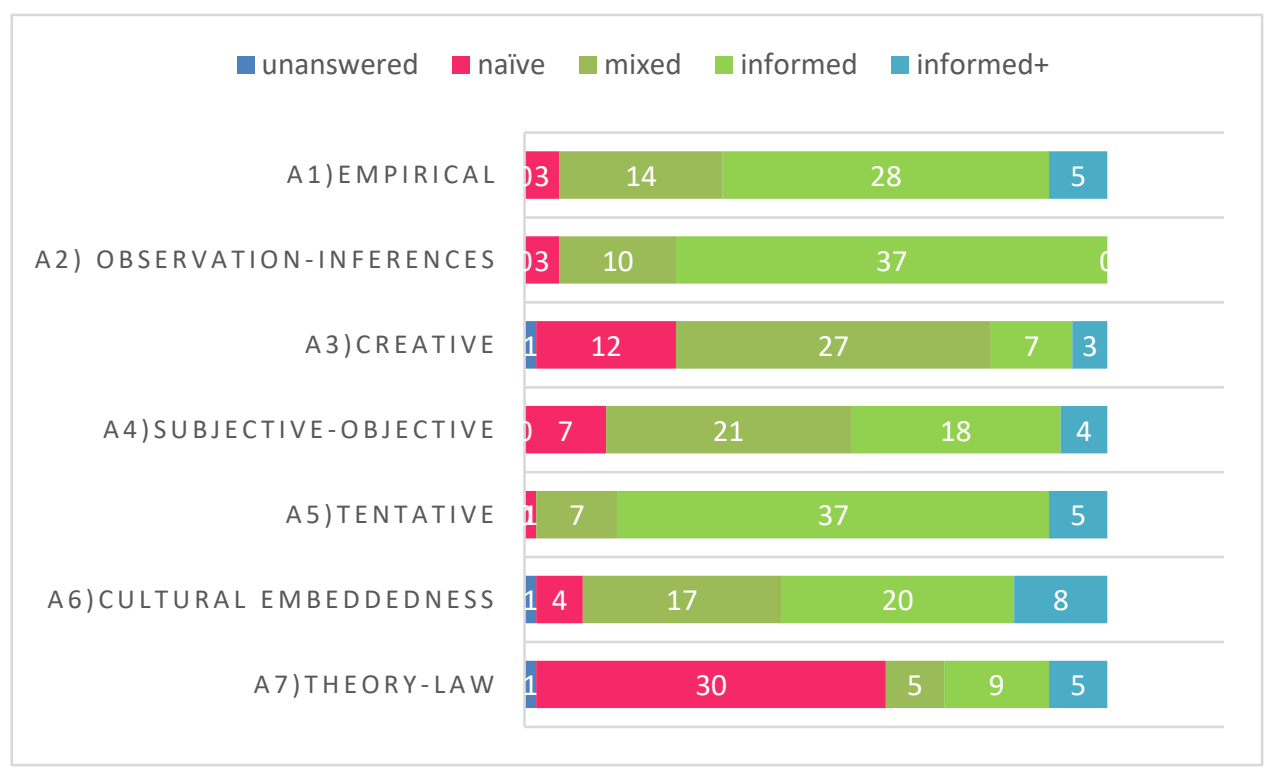

Figure 4. Results of VNOS-D+ Questionnaire from Teachers

Table 4. Results of VNOS Questionnaire from Teachers

\begin{tabular}{lccccc}
\hline NOSK aspects & $\mathrm{I}^{+}$ & $\mathrm{I}$ & $\mathrm{M}$ & $\mathrm{N}$ & $\mathrm{U}$ \\
\hline 1. empirical & 5 & 28 & 14 & 3 & 0 \\
2. difference between observations and inferences & 0 & 37 & 10 & 3 & 0 \\
3. is a product of creative thinking & 3 & 7 & 27 & 12 & 1 \\
4. subjective/objective & 4 & 18 & 21 & 7 & 0 \\
5. tentative & 5 & 37 & 7 & 1 & 0 \\
6. cultural and social embeddedness & 8 & 20 & 17 & 4 & 1 \\
7. difference between theories and laws & 5 & 9 & 5 & 30 & 1 \\
\hline
\end{tabular}

For our statistical estimations, we used confidence intervals to ensure, at a percentage defined at the beginning, that we have an interval within the range of the real value of the parameter we are interested in. The $95 \%$ confidence interval of the real range of teachers who give super informed and informed answers is provided by the relation (Kounias, Kolyva, Bagiatis \& Bora, 2009, p. 141-142):

$$
p-Z_{\frac{a}{2}} \sqrt{\frac{p(1-p)}{n}}<p<p+Z_{\frac{a}{2}} \sqrt{\frac{p(1-p)}{n}}
$$

where $\mathrm{p}=\frac{\text { Number of people from the sample who give the desired answer }}{\text { number of people from the sample }}$

$\mathrm{n}$ is the number of people from the sample

the desired confidence interval is (95\%), $\mathrm{Z}(\mathrm{a} / 2)=1,96$.

The sample results are presented in Table 5: 
Table 5. Statistical Analysis of Teachers' VNOS Results for I/I+ Answers

\begin{tabular}{lll}
\hline & \multicolumn{1}{c}{ NOSK aspects } & Range of values for 95\% confidence interval \\
\hline 1. & empirical & $66 \pm 13,1(52,9-79,1)$ \\
2. & differences between observations and inferences & $74 \pm 12,2(61,8-86,2)$ \\
3. & creative & $20 \pm 11,1(8,9-31,1)$ \\
4. & subjectivity/objectivity & $44 \pm 13,8(30,2-57,8)$ \\
5. & tentative & $84 \pm 10,2(73,8-94,2)$ \\
6. & social and cultural embeddedness & $56 \pm 13,8(42,2-69,8)$ \\
7. & difference between theories and laws & $28 \pm 12,4(15,6-40,4$ \\
\hline
\end{tabular}

Table 5 reveals three groups: the first group contains aspects 1, 2 and 5 and the second contains aspects 3 and 7. These two groups are statistically different - there is no overlap between them. The third group contains aspects 4 and 6 and there is a small overlap with the first and the second group.

The conclusions from Figure 4 and Tables 4 and 5 are:

- More than $2 / 3$ of the teachers are well aware (I/I+) of aspects 1, 2 and 5 : the empirical aspect (33/50), the difference between observations and inferences (37/50), and the tentative aspect (42/50).

- Almost half of the teachers are well aware of the subjective aspect (22/50) and the aspect about social and cultural embeddedness (28/50). Teachers' mixed views are higher for these aspects (21/50 and 17/50 respectively).

- The biggest issues seem to be a) on the difference between theories and laws, where only 14/50 are aware of it and $30 / 50$ teachers have naïve views, the most common being that Law is superior to Theory, something like a proven theory and b) that scientific knowledge is a product of creative thinking, since only 10/50 know of it. More than half (27/50) have mixed views.

It is noted that teachers who completed the questionnaire are superior to the average Greek science teacher, and consequently the results cannot be generalized for the whole population. However, they are still important, since they clearly demonstrate that even if those teachers who care to improve their teaching performance find difficulty in answering this questionnaire, then average teachers, with traditionally basic lessons, would provide worse responses (this is an inductive conclusion, there is no data from random sample).

\subsubsection{Interviews with Teachers}

Semi-constructed interviews took place with ten of the above teachers. The topics for discussion were the questions of the VNOS-D+ questionnaire, which NOSK aspects they were aware of and which they used in their lessons, each subject's relative chapters and some general school life questions. The interviews took place in May 2018 and additionally in October/November 2018.

Six out of ten teachers claimed that they had never heard of NOSK aspects before and had not thought of what these might be - or they might have heard the term but did not remember it. Four teachers who claimed to have previously heard of it, had either completed a PhD in Science Education (2 teachers) or attended PD-programs and conferences ( 2 teachers). They had no recollection of having been taught about it during their studies, definitely not explicitly.

Even though they did not know the collected NOSK aspects, they claimed that they teach intuitively some of them: all of them teach that scientific knowledge is empirically-based, through which scientists come to inferences, but they do not stress the difference between observations and inferences. They also teach the tentativeness of scientific knowledge. Two teachers claimed that they partially teach the subjectivity and creativity in scientific knowledge. Three teachers claimed that they teach the interactions between science and society. Regarding the difference between theories and laws, only one teacher knew of it and claimed to teach it. They all answered that they do not teach NOSK aspects explicitly and reflectively and they never assess students' knowledge on them.

All teachers claimed that the educational system does not incorporate NOSK in its lessons, but some of its elements may be included, although not taught, in textbooks, mostly in introductions and appendixes, which students traditionally do not read.

Their biggest teaching anxiety was to complete the curriculum in time and prepare their students for the exams, while avoid having problems with principals and parents. As they mentioned, "success in teaching is defined by how well you have prepared your students for exams and how successful they were." 


\subsection{Students' Assessment by Teachers in Relation to NOSK Aspects}

Students' studying (and, in general, trainees of every age) is mainly determined by the assessment type and the characteristics of the exams they take. What they will finally learn is not determined as much by the content of textbooks but by the exam type. The evaluation requirements affect students' studying strategies (Anagnostopoulou, 2015, p.177-178; Green \& Oates, 2009; Arons, 1990, p.365-366). To study whether students are assessed in their NOSK knowledge, we analyzed the topics of final exams.

For Lower Secondary School, Anagnostopoulou (2015) concluded that 4233 out of 4288 exam topics (1476 Physics, 1413 Chemistry, 1359 Biology), at a percentage of $99.6 \%$, assessed the body of knowledge. Only 15 exam topics, a percentage of $0.4 \%$, assess the knowledge "of science", where scientific research is included, part of which might be the knowledge of NOSK (p. 284). As for Higher Secondary School, almost no topic was related to NOSK - apart from 3 out of 1630 - as included in the Test Bank created by the Ministry of Education.

\subsection{Interviews with School Inspectors}

Seven Science School Inspectors from all regions of Greece were interviewed during January - June 2017 either face-to-face or via telephone. Four of them held a $\mathrm{PhD}$ in Science Education and one was a member of the authors' team for a textbook. The interview was a semi-constructed discussion on NOSK aspects and school life in the Secondary Education. Their responses did not differ significantly from teachers' opinions (see paragraph 3.2.2); however they emphasized the limited time for teaching and preparation for National Exams (which students take to enter university), a restriction that forces most teachers to prioritize solving complex mathematical exercises. School Inspectors claimed that only $15 \%$ of teachers use inquiry-based learning and around $2-5 \%$ of them teach most NOSK aspects regularly and explicitly ${ }^{4}$. They estimated that in most cases teaching contains the empirical and the tentative aspects, the latter as a path towards the truth.

In conclusion, School Inspectors argued that NOSK is not an objective in Science Education and it is not included in everyday teaching. They also claimed that most teachers are not aware of NOSK and are not being taught how to integrate it into their lessons.

\subsection{Students}

The final recipients of all the above are the students. Consequently, what graduates know about NOSK is another source of information, whether NOSK is being taught - and, most importantly, if it is being learned in Secondary School. Our research continues with the VNOS-D+ questionnaires and the interviews with graduate students.

\subsubsection{VNOS-D+ Questionnaire}

The sample consists of 149 first-year students in the School of Education of the Aristotle University of Thessaloniki. University students were chosen, instead of 12 th Grade students, as a means to obtain more objective results for the total student population. Specifically, university students in a big city come from all over Greece, from urban, rural and island areas, they have attended schools with different science teachers, and they potentially have received different stimuli. Furthermore, we considered that first-year graduates who attended university for only one month are not adjusted to university life yet and, as a result, they maintain the same mindset and have similar characteristics with high-school students. We conducted 30 interviews (20\% of the sample), where we discussed the VNOS questionnaire and other general questions. The research took place in November 2017.

Total results from students' answers for each category are presented in Figure 5 and Table 6 as follows: 


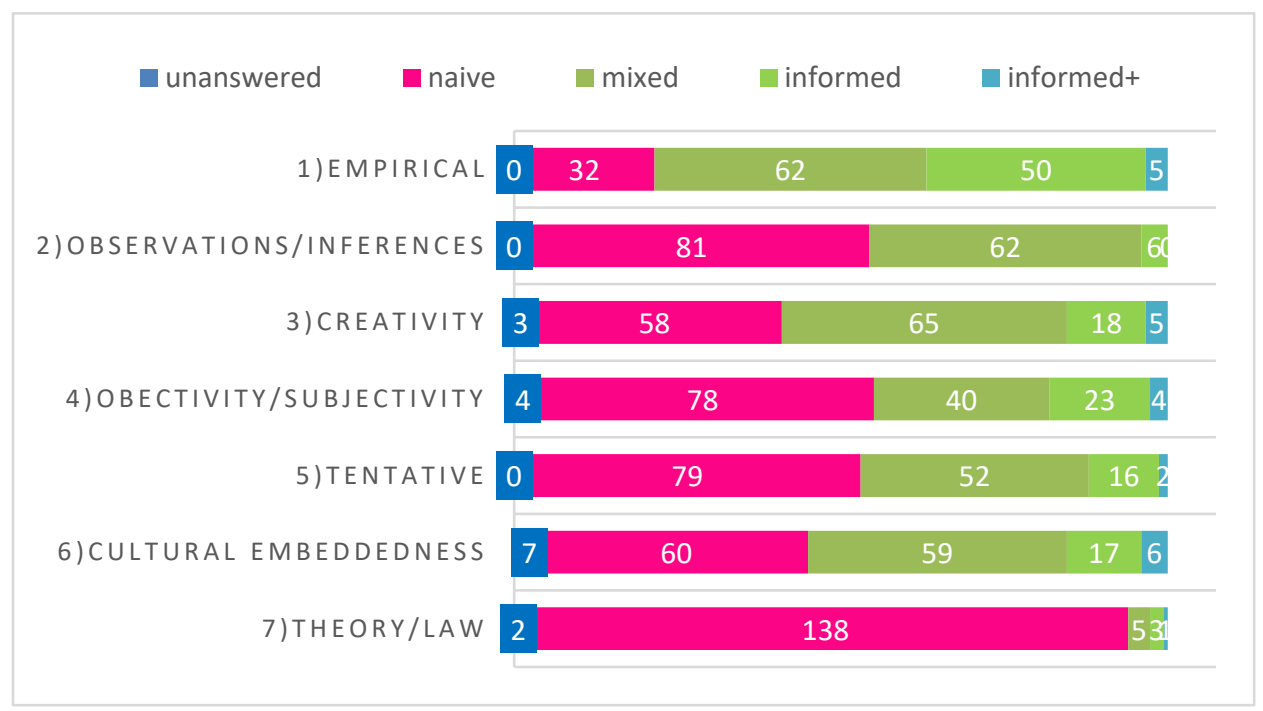

Figure 5. Results of VNOS-D+ Questionnaire from Students for Each NOSK Aspect

Table 6. Results of VNOS Questionnaire from Students

\begin{tabular}{lccccc}
\hline NOSK aspects & $\mathrm{I}+$ & $\mathrm{I}$ & $\mathrm{M}$ & $\mathrm{N}$ & $\mathrm{U}$ \\
\hline 1. empirical & 5 & 50 & 62 & 32 & 0 \\
2. difference between observations and inferences & 0 & 6 & 62 & 81 & 0 \\
3. is a product of creative thinking & 5 & 18 & 65 & 58 & 3 \\
4. subjective/objective & 4 & 23 & 40 & 78 & 4 \\
5. tentative & 2 & 16 & 52 & 79 & 0 \\
6. social and cultural embeddedness & 6 & 17 & 59 & 60 & 7 \\
7. difference between theories and laws & 1 & 3 & 5 & 138 & 2 \\
\hline
\end{tabular}

Table 7 results from the data of Table 6. On its second column there is the number of students that give informed and super informed answers and on the third column is the 95\% confidence interval (Kounias et el, 2009, p.141-142) where the value of the wider population of Greek graduate students can be found.

Table 7. Statistical Analysis from Students' VNOS Results for I/I+ Answers

\begin{tabular}{|c|c|c|}
\hline NOSK aspects & $\begin{array}{l}\text { Number of } \mathrm{I}^{+} \mathrm{I}^{+} \\
\text {answers }\end{array}$ & Range of values for $95 \%$ confidence interval \\
\hline 1. Empirical & 55 & $36,9 \pm 7,729,2-44,9$ \\
\hline 2. difference between observations and inferences & 6 & $4,0 \pm 3,2 \quad 0,8-7,2$ \\
\hline 3. creative & 23 & $15,4 \pm 5,89,6-21,2$ \\
\hline 4. subjective/objective & 27 & $18,1 \pm 6,211,9-24,3$ \\
\hline 5. tentative & 18 & $12,1 \pm 5,17,0-17,2$ \\
\hline 6. social and cultural embeddedness & 23 & $15,4 \pm 5,89,6-21,2$ \\
\hline 7. difference between theories and laws & $4^{5}$ & Lower than $3.4 \pm 2,9$ \\
\hline
\end{tabular}

The conclusions which arise from Table 7 are:

- Students' knowledge on the empirical aspect is statistically distinguished, since $30-40 \%$ of students seem to be aware of it.

- Students' knowledge on the tentative and subjective aspects, the aspect about creative thinking and the social and cultural embeddedness do not differ significantly. Students' knowledge on all these aspects is around 10-20\%.

- The difference between observations and inferences and between Theories and Laws seem not to be understood by students, even though the former is included in textbooks and teachers seem to be aware of it. This will be further 
discussed in paragraph 4 .

\subsubsection{Interviews with Students}

After having scored the answers on VNOS-D+ questionnaires for the first time, we interviewed 30 students (20\% of the total sample, as guided by the creators of the questionnaire), during December 2017 - January 2018. Each interview consisted of three parts: a) every student was asked to answer again all the VNOS questions orally and explain what they wrote. The results of this part of the interviews formed the final scoring of the questionnaire. $b$ ) Students were asked to answer whether they were taught about NOSK during their school years and whether they were assessed on that. They were also asked to comment on c) various general matters about their school life and education, which were used in a different research stage.

All students claimed that they had never heard the term "nature of scientific knowledge" before, or at least they did not remember it. When asked whether their daily lessons included NOSK aspects (in order to understand the question, they were given a sheet of paper with the NOSK aspects and discussed them briefly with the researcher), 10 students answered that they had never referred to any of them in any subject, whereas 15 students remembered having heard that knowledge is empirically-based (the empirical aspect) and has an inferential character, but they were not aware of the difference between observations and inferences. Three students claimed that in their Physics classes there were extensive references on the evolution of scientific ideas. They discussed that scientific knowledge is subject to change over time (the tentative aspect), but it seemed as if they only referred to the past. Also, students had the impression that these references were only for their own information and were not part of the actual lesson. Finally, one student participated in an eTwinning program regarding "how science works", where most NOSK aspects were presented, although not in an organized and explicit manner.

To sum up, the questionnaires and interviews with students indicated that students were not taught about the NOSK aspects in an organized manner and any knowledge originates from implicit teaching.

\section{Discussion}

In conclusion, the Greek educational system is not oriented towards the integration of NOSK aspects in science teaching. The curriculum objectives do not contain it and textbooks, which tend to follow the curriculum, include only a few aspects, mainly the empirical and, at a smaller degree, the tentative one, but without referring to them by their names. Also, the term "nature of scientific knowledge" or any similar term is not used. Teachers usually follow the textbooks and do not mention NOSK in their lessons. However, even when they do, they do not assess them. School inspectors, with a wider understanding of what is happening in schools, regard that NOSK is not a goal for Science Education and, generally, it is not included in daily lesson planning. This is consistent with the observation that most students have naïve views on NOSK aspects. Regarding the difference between observations and inferences, interestingly, even though it is clearly mentioned in textbooks, teachers are the only ones who are aware of it. This indicates that probably teaching is not explicit and reflective, as suggested in the literature (Lederman \& Lederman, 2014), and students are not becoming aware of it.

Schematically, all of the above are illustrated in Figure 6, using the sub-triangles of CHAT (Plakitsi, 2013):

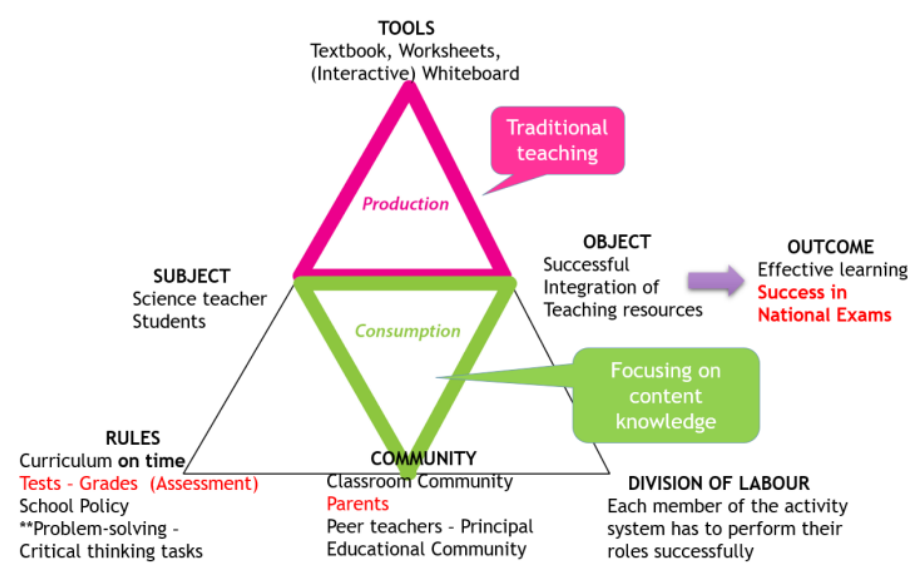

Figure 6. A typical Science Class Activity System in Greek Secondary Education, as Resulting from Our Research 
Contradictions arisen from students, parents and principals who insist that teaching should lead to success in all National exams. However, at the same time, students feel that what they are being taught does not reflect their interests.

In relation to the embeddedness of NOSK aspects, the sub-triangle of production is interesting, since teachers who wish to integrate NOSK in their teaching must design new lesson plans that demand extra time and effort. The sub-triangle of consumption is also interesting, since the same teachers need to persuade the community (parents, students, principals and peer teachers) that NOSK teaching is in favor of the evolutionary learning route of students, in order to be accepted.

Other studies from Greece (e.g. Kampourakis, 2017) and abroad, draw similar conclusions, validating our research. For instance, in Lebanon (El-Takach \& Yakoubian, 2020) NOSK is not included in the curriculum and teachers have no formal pedagogical training. Regarding books, Abd-El-Khalick et al (2017) claim that NOSK aspects are included in the introduction chapters of most books. Lederman and Lederman (2014) in their review article, claim that a plethora of studies conclude that both teachers and students have naïve views on most NOSK aspects and that NOSK teaching, when it takes place, is not explicit and reflective. The case of Greece is not disheartening; on the contrary, it has many similarities with other countries.

\section{Conclusion}

In this study it was presented the multi-faceted method that we used to study all the components of the Greek Secondary Education system in relation to NOSK. The fact that all tools gave the same results and agreed with each other, is a factor that validates our research. Other factors are the agreement with other Greek studies, that examine specific components of the Greek Secondary Education, plus the consistency with international studies.

Furthermore, the particularities of the Greek educational system were brought out, which are useful for the whole project. Following up in the wider project, a PD-program for science teachers can be organized which would take into consideration: i) the results of the present research, ii) the literature of NOSK and iii) the CHAT framework. The objective of the program would be the training of teachers on a) NOSK aspects, b) possible teaching approaches and on c) ways of being incorporated in the present curriculum, through the design of competent lesson plans.

In the future, we consider that the Greek government could organize a wider project, similar to the Turkish BIDOMEG one (see Introduction). The project could start with a quantitative record, similar to the one presented here, for a wider and more representative number of teachers and students. The method of the present study could be used as a model.

\section{Notes}

1. First-year students in their first month of university were regarded as graduate students, because they come from all regions of Greece and have followed all specializations.

2. In some countries, teachers have no subject-specific university degrees and may feel unfamiliar with the subject they are teaching (McDonald \& Abd-El-Khalick, 2017a). This is not the case with Greece.

3. https://www.physport.org/assessments/assessment.cfm?A=VNOS

4. School inspectors mean that this is the rate of teachers nationally that are aware of NOSK aspects and teach them.

5. The relation that gives the confidence interval is valid if $n p \geq 5$, so it is not valid on this case. But, if 5 students gave this answer instead of 4 , then $n p \geq 5$, it would be valid and the respective interval would be $3.4 \pm 2,9$, which means $0.5-6.3$. So, in our case it is a bit smaller, which is obvious enough.

\section{References}

Abd-El-Khalick, F., Waters, M., \& Le, A. P. (2008). Representations of Nature of Science in High School Chemistry Textbooks over the Past Four Decades. Journal of Research in Science Teaching, 45(7), 835-855.

Abd-El-Khalick, F. (2014). The Evolving Landscape Related to Assessment of Nature of Science. In Lederman N.G. and Abell S. K. (Eds.), Handbook of Research on Science Education, New York, 621-650. https://doi.org/10.1002/tea.20226

Abd-El-Khalick, F., Myers, J., Summers, R., Brunner, J., Waight, N., Wahbeh, N., Zeineddin, A., \& Belarmino, J. (2017). A Longitudinal Analysis of the Extent and Manner of Representations of Nature of Science in U.S. High 
School Biology and Physics Textbooks. Journal of Research in Science Teaching, 54(1), 82-120. https://doi.org/10.1002/tea.21339

Akerson, V., \& Abd-El-Khalick, F. (2005). How Should I Know About What Scientists Do? I'm Just a Kid: Fourth-Grade Students' Conceptions of Nature of Science. Journal of Elementary Science Education, 17(1), 1-11.

Allchin, C. (2011). Evaluating Knowledge of the Nature of (Whole) Science. Science Education, 95(3), 518-542.

Allchin, D., Andersen, H. M., \& Nielsen, K. (2014). Complementary Approaches to Teaching Nature of Science: Integrating Student Inquiry, Historical Cases and Contemporary Cases in Classroom Practice. Science Education, 98, 461-486. https://doi.org/10.1002/sce.21111

Anagnostopoulou, K. (2015). Assessed students' competencies in the Greek school framework and Pisa survey (PhD thesis). Patras, greek language.

Arons, A. (1990). A guide to introductory physics teaching. John Wiley \& Sons, Inc. New York.

Barma, S., Lacasse, M., \& Masse-Morneau, J. (2014). Engaging discussion about climate change in a Quebec secondary school: A challenge for science teachers, Learning, Culture and Social Interaction. http://doi.org/10.1016/j.lcsi.2014.07.004

BouJaoude S., \& Santourian G. (2012). The Status of the Nature of Science in Science Education in Lebanon. In: Khine M. (Eds.), Advances in Nature of Science Research. Springer, Dordrecht.

Clough, M. P. (2007). Teaching the Nature of Science to Secondary and Post-Secondary Students: Questions rather than Tenets. The Pantaneto Forum, 25. Retrieved from http://www.pantaneto.co.uk/issue25/front25.htm, January. Republished (2008) in the California Journal of Science Education, 8(2), 31-40.

DiGiuseppe, M. (2014). Representing Nature of Science in a Science Textbook: Exploring author - editor- publisher interactions. International Journal of Science Education, 36(7), 1061-1082. https://doi.org/10.1080/09500693.2013.840405

Dogan, N., \& Abd-El-Khalick, F. (2008). Turkish Grade 10 Students' and Science Teachers' Conceptions of Nature of Science: A National Study. Journal of Research in Science Teaching, 45(10), 1083-1112. https://doi.org/10.1002/tea.20243

El-Takach, S., \& Yacoubian, H. A. (2020). Science teachers' and their students' perceptions of science and scientists. International Journal of Education in Mathematics, Science and Technology, 8(1), 65-75. https://doi.org/10.46328/ijemst.v8i1.806

Engeström, Y. (1987). Learning by expanding: An activity-theoretical approach to developmental research. Helsinki, Orienta-Konsultit.

Engeström, Y. (2001). Expansive Learning at Work: Toward an activity theoretical reconceptualization. Journal of Education and Work, 14(1), 133-156. https://doi.org/10.1080/13639080020028747

Engeström, Y. (2009). Expansive learning: Toward an activity-theoretical reconceptualization. Chapter 4 in "Contemporary Theories of Learning: Learning Theorists in Their Own Words" author: Illeris, Knud. Publisher: Taylor \& Francis Routledge

Erduran, S., \& Dagher, Z. R. (2014). Reconceptualizing the Nature of Science for Science Education: Scientific Knowledge. Practices and Other Family Categories, the Netherlands, Springer.

Hasan, H., \& Kazlauskas, A. (2014). Activity Theory: who is doing what, why and how? In H. Hasan (Eds.), Being Practical with Theory: A Window into Business Research (pp. 9-14). Wollongong, Australia: THEORI.

Green, S., \& Oates, T. (2009). Considering alternatives to national assessment arrangements in England: possibilities and opportunities. Educational Research, 51(2), 229-245. https://doi.org/10.1080/00131880902891503

Igira, F. T., \& Gregory, J. (2009). Cultural Historical Activity Theory. In Handbook of Research on Contemporary Theoretical Models in Information Systems (pp. 434-454).

Jenkins, E. W. (2013). The 'nature of science' in the school curriculum: the great survivor. Journal of Curriculum Studies, 45(2), 132-151. https://doi.org/10.1080/00220272.2012.741264

Kampourakis, K. (2017). Nature of Science Representations in Greek Secondary School Biology Textbooks. In McDonald C., \& Abd-El-Khalick F. (Eds.), Representations of Nature of Science in School Science Textbooks, Routledge, New York, 118-134. 
Kolokouri, E., \& Plakitsi, K. (2016). CHAT Approach of Light and Colors in Science Teaching for the Early Grades. World Journal of Education, 6(4), 1-13.

Kornelaki, A., \& Plakitsi, K. (2018). Thunderbolt hunt. Educational Program for Students from 5 to 9 Years Old in the Archaeological Museum of Ioannina. World Journal of Education, 89(4), 87-101.

Koumara, A., \& Plakitsi, K. (2017b). The nature of science in lower secondary school: the case of Greece. Science Education: Research and Praxis, (64-65), 104-114. Retrieved from http://www.lib.uoi.gr/serp/

Koumara, A., \& Plakitsi, K. (2019). Nature of Science and Cultural Historical Activity Theory. Ioannina, ISCAR Regional Conference.

Kounias, S., Kolyva Machaira, F., Bagiatis, K., \& Bora Senta, E. (2009). Introduction to Statistics. Christodoulidi Publications, Thessaloniki (Greek language).

Leden, L., Hansson, L., Redfors, A., \& Ideland, M. (2015). Teachers' Ways of Talking About Nature of Science and Its Teaching. Science \& Education, 24, 1141-1172.

Lederman, N., Abd-El-Khalick, F., Bell, R., \& Schwartz, R. (2002). Views of Nature of Science Questionnaire: Toward Valid and Meaningful Assessment of Learners' Conceptions of Nature of Science. Journal of Research in Science Teaching, 39(6), 497-521.

Lederman, N., Antink, A., \& Bartos, S. (2014). Nature of Science, Scientific Inquiry and Socio-Scientific Issues Arising from Genetics: A Pathway to Developing a Scientifically Literate Citizenry. Science \& Education, 23, 285-302.

Lederman, N., \& Lederman J. (2014). Research on Teaching and Learning of Nature of Science. In Lederman, N. G., \& Abell, S. K. (Eds.), Handbook of Research on Science Education, New York, 600-620.

Lederman, N. (2019). Contextualizing the Relationship between Nature of Scientific Knowledge and Scientific Inquiry: Implications for Curriculum and Classroom Practice. Science \& Education, 28, 249-267.

Matthews, M. R. (1997). Editorial. Science \& Education, 6, 323-329.

Matthews, M. R. (2012). Changing the focus: From nature of science (NOS) to features of science (FOS). In M. S. Khine (Ed.), Advances in nature of science research: Concepts and methodologies (pp. 3-26). Dordrecht, the Netherlands: Springer.

McComas, W. (2017). Understanding how science works: The nature of science as the foundation for science teaching and learning. School Science Review, 98(365), 71-76.

McDonald, C., \& Abd-El-Khalcik, F. (2017a). Representations of Nature of Science in School Science Textbooks, In McDonald, C., \& Abd-El-Khalick, F. (Eds.), Representations of Nature of Science in School Science Textbooks, Routledge, New York, 1-19.

McDonald, C., \& Abd-El-Khalcik, F. (2017b). Where to From Here? Implications and Future Directions for Research on Representations of Nature of Science in School Science Textbooks. In McDonald, C., \& Abd-El-Khalick, F. (Eds.), Representations of Nature of Science in School Science Textbooks, Routledge, New York, 215-231.

Naser, I. A. S. (2018). The Degree of Including International Standards of Science Education in the Physics Syllabus of Palestinian Secondary Schools. World Journal of Education, 8(3), 18-30. https://doi.org/10.5430/wje.v8n3p18

Roth, W. M., \& Lee, Y. J. (2007). "Vygotsky's neglected legacy": Cultural-historical activity theory. Review of Educational Research, 77(2), 186-232.

Piliouras, P., Plakitsi, K., \& Nasis, G. (2015). Discourse Analysis of Science Teachers Talk as a Self-reflective Tool for Promoting Effective NOS Teaching. World Journal of Education, 5(6), 96-107. https://doi.org/10.5430/wje.v5n6p96

Plakitsi, K., Kassetas, I. A., Smyrnaiou, Z., Develaki, M., Diakonou, M., Kanderakis, N., Fanidis, C., Taramopoulos, T., \& Papatsimpa, L. (2011/2014). New Curriculum for compulsory education: Science for Lower Secondary Schools. Institute of Educational Policy, Ministry of Education. (Greek language).

Plakitsi, K. (2013). Activity Theory in Formal and Informal Education. In K. Plakitsi (Ed.), Activity Theory in Formal and Informal Science Education. Cultural and Historical Perspectives on Science Education (Research Dialogs). Sense Publishers, 17-26, Rotterdam. https://doi.org/10.1007/978-94-6091-317-4_1 
Schwartz, R., \& Lederman, N. (2008). What Scientists Say: Scientists' views of nature of science and relation to science context. International Journal of Science Education, 30(6), 727-771.

Stefanidou, C., \& Skordoulis, C. (2017). Primary Student Teachers' Understanding of Basic Ideas of Nature of Science: Laws, Theories and Models. Journal of Studies in Education, 7(1), 127-153. https://doi.org/10.5296/jse.v7i1.10599

Thye, T. L., \& Kwen, B. H. (2004). Assessing the Nature of Science Views of Singaporean Pre-Service Teachers. Australian Journal of Teacher Education, 29(2), 1-10.

VanDijk, E. (2011). Portraying Real Science in Science Communication. Science Education, 95(6), 1086-1100. https://doi.org/10.1002/sce.20458

Yalaki, Y., Dogan, N., Irez, S., Dogan, N., Cakmakci, G., \& Kara E. B. (2019). Measuring Nature of Science Views of Middle School Students. International Journal of Assessment Tools in Education, 6(3), 461-475.

\section{Copyrights}

Copyright for this article is retained by the author(s), with first publication rights granted to the journal.

This is an open-access article distributed under the terms and conditions of the Creative Commons Attribution license (http://creativecommons.org/licenses/by/4.0/). 